\title{
Histopathological and histomicrobiological study of root canal therapy medication, comparison of calcium hydroxide versus gutta-percha with zinc oxide/eugenol in the teeth of dogs ${ }^{1}$
}

\author{
Léslie M. Domingues-Falqueiro ${ }^{2 *}$, Marco A. Gioso ${ }^{3}$ and \\ João G. Padilha Filho ${ }^{4}$
}

\begin{abstract}
Domingues-F. L.M., Gioso M.A. \& Padilha Filho J.G. 2007. Histopathological and histomicrobiological study of root canal therapy medication, comparison of calcium hydroxide versus gutta-percha with zinc oxide/eugenol in the teeth of dogs. Pesquisa Veterinária Brasileira 27(2):71-74. Departamento de Cirurgia da Faculdade de Medicina Veterinária e Zootecnia, Universidade de São Paulo, Av. Prof. Dr. Orlando de Marques de Paiva 87, Bloco 8superior, Cidade Universitária, São Paulo, SP 05508-000, Brazil. E-mail: lesliedf@usp.br

The presence of microorganisms in dental structures with experimentally induced necrosis was evaluated. The materials were tested to evaluate their antimicrobial activity and tissue repair efficacy. Four dogs were used in this experiment, with a total of 64 roots of premolar teeth, divided into three groups. The root canals of Group I were filled with gutta-percha and zinc oxide/eugenol cement; Group II were filled with calcium hydroxide, and Group III were not filled. All animals were clinically and radiographically examined 15 days after surgery and then again every subsequent 15 days until 120 days, when the teeth were extracted en bloc. Histopathological analysis showed inflammatory infiltration, cement and bone resorption and necrotic tissue in the apical delta in different proportions. Histomicrobiological analysis showed the presence of microorganisms inside the teeth structures, with different concentrations according to the treatment used. There was statistical significance between the groups ( $p>0.05$ ). Gutta-percha with zinc oxide/eugenol demonstrated good antimicrobial activity; calcium hydroxide was not efficient. The conclusion of this study is that gutta-percha with zinc oxide/eugenol is the better protocol for filling root canals in dogs.
\end{abstract}

INDEX TERMS: Apical delta, endodontic, gutta-percha, calcium hidroxide, microorganisms, dogs.

RESUMO.- [Avaliação histopatológica e histomicrobiológica de dentes de cães, após tratamento endodôntico com hidróxido de cálcio e guta-percha com óxido de zinco e eugenol.] Avaliou-se a presença de microrganismos nas estruturas dentais com necrose pulpar induzida experimentalmente, testando a eficácia de materiais com relação à atividade antibacteriana

\footnotetext{
${ }^{1}$ Received on October 10, 2006.

Accepted for publication on January 15, 2007.

${ }^{2}$ Pós-Doutoranda do Departamento de Cirurgia, Faculdade de Medicina Veterinária e Zootecnia (FMVZ), Universidade de São Paulo (USP), Av. Prof. Dr. Orlando de Marques de Paiva 87, Bloco 8-superior, Cidade Universitária, São Paulo, SP 05508-000, Brazil. "Correspondi g author: lesliedf@usp.br

${ }^{3}$ Departamento de Cirurgia, FMVZ, USP.

${ }^{4}$ Departamento de Cirurgia, Faculdade de Ciências Agrárias e Veterinárias, Universidade Estadual Paulista (Unesp), Campus de Jaboticabal, Rod. Prof. Paulo Donato Castelane, Km 5, Jaboticabal, SP 14884-900, Brazil.
}

e influência no reparo tecidual. Utilizaram-se quatro cães, totalizando 64 raízes, provenientes de pré-molares, divididas em grupos. O Grupo I foi obturado com guta percha e cimento à base de óxido de zinco e eugenol, o Grupo II, com hidróxido de cálcio e o Grupo III, não foram obturados. Todos tiveram controle clínico e radiográfico quinzenal e após 120 dias, foram extraídos em bloco para análises. A histopatologia evidenciou infiltrado inflamatório, reabsorção cementária e óssea e tecido necrótico no delta apical, em diferentes proporções. A histomicrobiologia revelou presença de microrganismos nas estruturas estudadas, variando de acordo com o tratamento utilizado. Os resultados foram submetidos à análise estatística e foram significantes entre si $(p>0,05)$. A guta-percha com óxido de zinco e eugenol apresentou-se eficaz com relação à atividade antibacteriana. $O$ hidróxido de cálcio não se mostrou eficaz. Os resultados obtidos através da utilização destes materiais deixaram evidente que a guta-percha associada ao óxido de 
zinco e eugenol é o melhor protocolo a ser utilizado no tratamento endodôntico em cães.

TERMOS DE INDEXAÇÃO: Delta apical, endodontia, guta-percha, hidróxido de cálcio, microrganismos.

\section{INTRODUCTION}

During the treatment of chronic periapical endodontic lesions the complex internal anatomy of teeth contributes to therapy failure with the millions of dentine tubules and their numerous ramifications (Wada et al. 1998) having both aerobic and anaerobic microbial contamination (Almeida 1993, Leonardo et al. 1993, Soares 1999).

With endodontic treatment in dogs microorganisms are the primary consideration since bacteria in the dentine tubules, foramina and apical delta seem to be related to treatment failure with the apical delta being the most important of these structures (Gioso 2003).

During root canal therapy of dogs, the foramina are not directly affected by the chemical or mechanical procedures. There is no information on whether the apical delta is directly irrigated or, whether after the root canal has been filled with endodontic cements or gutta-percha, the microorganisms are destroyed or if they are still capable of reproducing.

The literature does not contain information on the presence of microorganisms in the foramina in the apical delta of dogs. It is important to understand the effect of bacterial pathogenesis on these tissues in order to evaluate the efficacy of proposed treatments Holland et al. (2005) and Sipert et al. (2005) observed the process of tooth repair in dogs after filling the canal, concluding that calcium hydroxide cement was the best material to induce apical repair.

The purpose of this study is to evaluate the presence of microorganisms in the root canal, dentine tubules and especially in the apical delta in the teeth of dogs with experimentally induced pulp necrosis. The intention is to test the antimicrobial and tissue repair efficacy of gutta-percha with zinc oxide/ eugenol cement compared with calcium hydroxide.

\section{MATERIALS AND METHODS}

The present study was performed in four mixed breed dogs, maintained at the kennel of the Clinical and Surgery Department of the Veterinary Medicine School of the University State of São Paulo and was approved by the school Ethics Committee. The second, third and fourth lower premolar teeth of both sides and the second and third upper premolar teeth of the left side of the maxilla were used in the experiment.

\section{Anesthetic Procedure}

The anesthetic protocol utilized for the animals during the surgery procedures (day 0 , day 60 and day 120 ) is described next.

Preanesthetic medication was performed with an intramuscular combination of acepromazine $(0,05 \mathrm{mg} / \mathrm{kg})$ and meperidine $(2 \mathrm{mg} / \mathrm{kg})$, followed by intravenous induction with propofol $(5 \mathrm{mg} / \mathrm{kg})$. For maintenance isoflurane in a $100 \%$ oxygen circuit was used. All animals were maintained on intravenous lactate ringer by catheter placement at the cephalic vein.

Intraoral radiographies were performed every 15 days, until day
120. During these procedures the animals were anesthetized according to the anesthetic protocol described above, except that they were maintained with propofol.

All patients were monitored during the anesthetic procedure by pulse oximeter, indirect blood pressure, electrocardiogram and temperature.

At the end of the day 0 procedure the animals were medicated with a subcutaneous injection of tramadol $(2 \mathrm{mg} / \mathrm{kg})$ and ketoprofen $(1 \mathrm{mg} / \mathrm{kg})$. Postoperative care consisted of oral administration of ketoprofen $(1 \mathrm{mg} / \mathrm{kg} / \mathrm{SID})$ for 5 days with normal diet.

\section{Surgery procedure}

At day 0 , the animals were anesthetized and periapical radiographs of all experimental teeth were taken using the parallel and bisecting angle techniques. Twenty one of the 32 teeth were opened at the crown to expose the pulp chamber. The remaining 11 teeth were kept intact during this first phase. At the end of the first phase the animals were medicated with anti-inflammatory drugs to control the inflammatory reaction and pain.

After 60 days (considered to be the contamination period) the root canals in were opened to expose the coronary chamber, these comprised the control group.

The classical technique of root canal therapy, described by Harvey \& Emily (1993), was performed in this study, as following. Radiographs of the experimental teeth were taken to evaluate the root canal and periapical region. Endodontic files were placed into each root canal to determine the canal length and another radiograph was performed to verify the file depth and the working length. The root canal was then cleaned and shaped using files in a sequential order and with predetermined length together with irrigation and lubrication with sodium hypochlorite and canal lubricant (endoPTC $®)$. The root canal was dried with absorbent paper points and then obturated with the filling materials, either calcium hydroxide or zinc-oxide/ eugenol cement with gutta-percha cones.

The 64 roots were divided into three experimental groups: Group I (22 roots): gutta-percha with zinc oxide/eugenol cement; Group II (20 roots): calcium hydroxide paste; Group III (22 roots): control.

After 120 days, the teeth were extracted en bloc (teeth and periodontal tissue). A mucoperiosteal flap is raised over the experimental teeth were performed with a 15 scalpel blade and scissor, followed by ostectomy with chisel and hammer. The specimens were fixed and demineralized for preparation of histological sections. The sectioned specimens were dyed with hematoxylin-eosin (HE) and Brown \& Hopps (1973) methods were used to visualise the microorganisms. The non parametric variability method of the Kruskal-Wallis was used for statistical analysis and the results were then compared by the Dunn multiple comparison test.

\section{RESULTS AND DISCUSSION}

Histological analysis of the periapical region showed areas of inflammation and resorption of the apical cement, with dentine structure exposure in many cases. The depth of inflammation and the extent of bone resorption revealed by histopathological analysis indicated a long term infection (Silveira 1997).

This study suggests significantly different antibacterial activity for each substance used $(p>0,05)$. Sixty days after root canal filling, an inflammatory reaction was evident in all samples but with different levels of intensity (Fig.1).

As expected Group III (control) had the highest level of inflammation, with the majority of the sample classified as "severe" (Fig.2). However, Group II presented the same number 


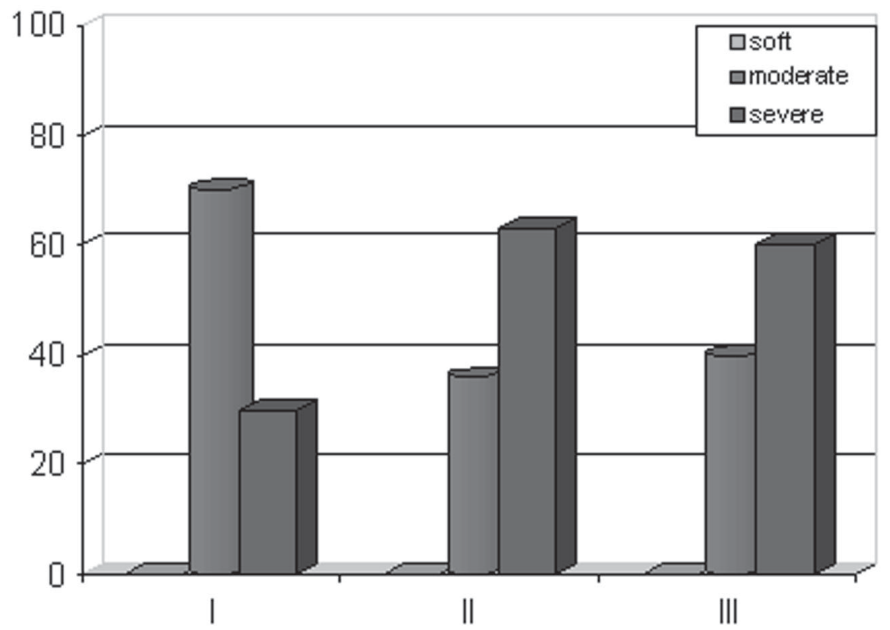

Fig.1. Inflammation was present in all samples. This shows differences of intensity (Group I: gutta-percha with oxide zinc/eugenol; Group II: calcium hydroxide; and Group III: control), p>0,05.

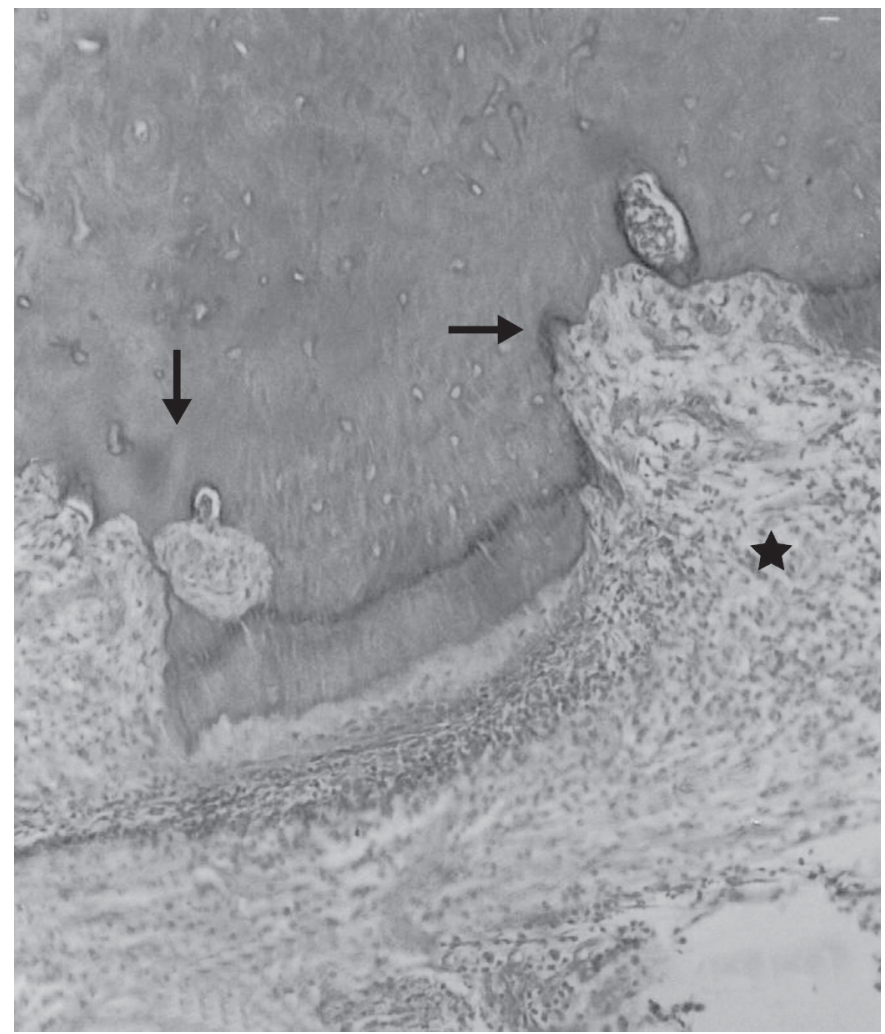

Fig.2. Root apex (Group III: control), showing cement resorption (arrows), and inflammation (star). HE, obj.10.

of inflamed roots suggesting that calcium hydroxide treatment did not reduce inflammation. The bacterial data (Fig.3) showed that calcium hydroxide (Group I) was also a less effective antimicrobial treatment than zinc oxide/eugenol cement with guttapercha cones (Group II), p>0,05.

Bone resorption (RO), cement resorption ( $\mathrm{RC}$ ) and necrotic tissue at the apical delta (TN) were also analysed. Groups I and II had a similar response with Group III showing the highest level of all three parameters. The tested groups (I and II) had a high index of RO, RC and TN but with a low percentage, due to the presence of low levels of inflammatory infiltrate. This data suggests that more time is needed to evaluate the effects on tissue repair.

The method used for the histomicrobiological analysis visualised both gram-positive and gram-negative bacteria but, in this study, only the gram-positives microorganisms were of interest (Almeida 1993, Bonetti Filho 2000).

According to other researchers the process used for histological staining results in a reduction in the observed bacterial level within the tissues. The apparent absence of gramnegative bacteria in this study could be a result of the complete disintegration of these microorganisms at the acid stage of demineralization (Silveira 1997).

Group I treatment was the most effective at reducing bacteria followed by Groups II and III with the control (Group III) having the greatest concentration of bacteria (Fig.3). The results were statistically significantly different.

Consistent with the findings of Silveira (1997) microorganisms were found not only in the root canal space but also in the dentine tubules (Fig.4).

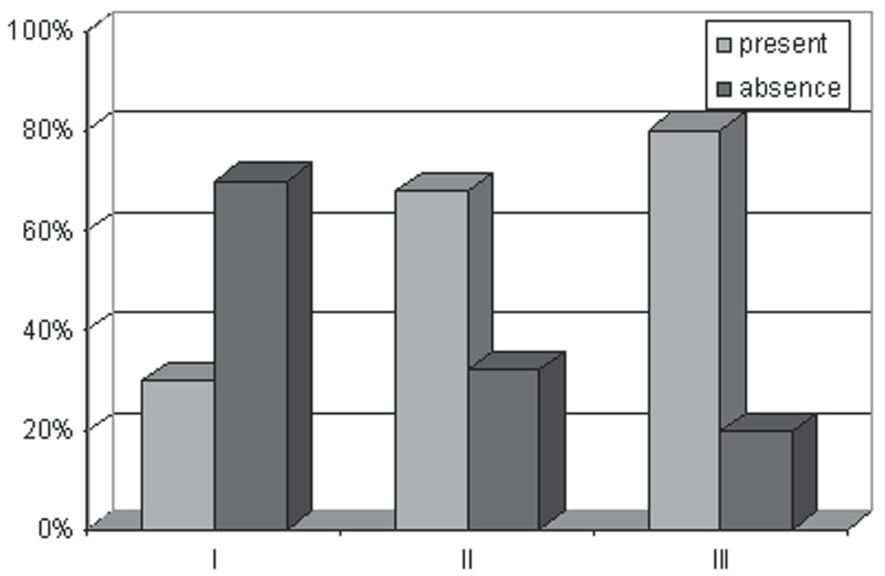

Fig.3. Microorganisms present or absence in the 60 dog root (Group I: gutta-percha with oxide zinc/eugenol; Group II: calcium hydroxide; and Group III: control), p>0,05.

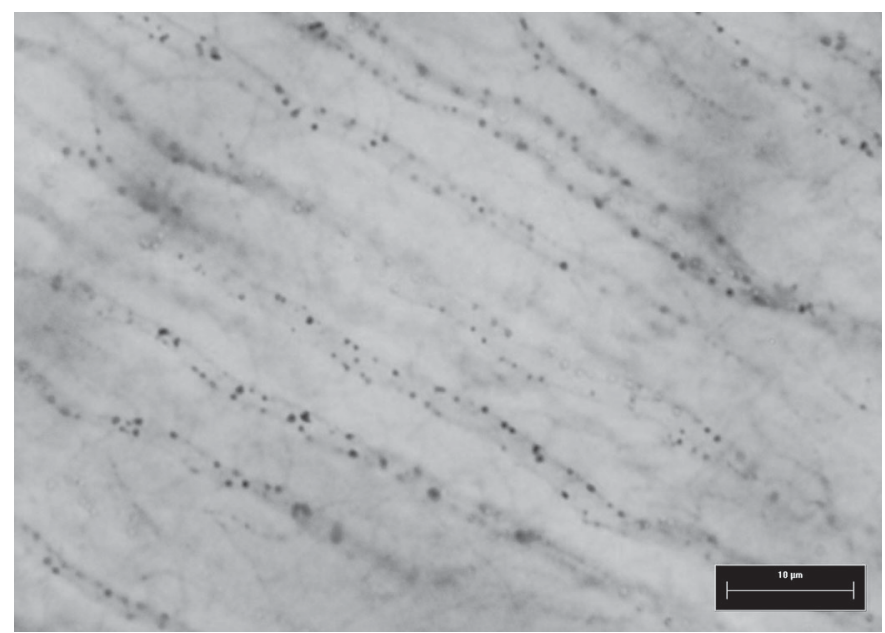

Fig.4. Bacteria in the dentinary tubules (arrow). Group II: calcium hydroxide. BH (Brown \& Hopps 1973), obj.100. 
Group I had the lowest bacterial concentration but the greatest concentration of bacteria was in the apical delta, the most difficult region for the test materials to access. This fact could be explained by the viscosity of the zinc oxide/eugenol cement reducing its ability to penetrate the foramina. By contrast this group was most effective at eliminating bacteria in the dentine tubules. Overall this group had the lowest contamination of bacteria.

In Group II microorganisms were found in the dentine tubules and in other regions showing that calcium hydroxide alone did not penetrate the dentine tubules well or was a less effective bactericidal agent. In Group III bacteria were present in all regions except the apical delta. The period of time of oral exposure was short and therefore bacteria probably need more time to reach the apical delta.

The gutta-percha with zinc oxide/eugenol cement showed effective antibacterial activity and the calcium hydroxide was less effective. The conclusion of this study is that the guttapercha with zinc oxide/eugenol is a better protocol to fill the root canal in dogs.

Acknowledgments.- To the "Fundação de Amparo à Pesquisa do Estado de São Paulo" (FAPESP) for funding this Project.

\section{REFERENCES}

Almeida W.A. 1993. Diferentes técnicas de tratamento de canais radiculares em dentes de cães com reação periapical crônica. Estudo radiográfico e histobacteriológico da reparação apical e periapical. Dissertação de Mestrado em Endodontia, Faculdade de Odontologia, Universidade Estadual Paulista, Araraquara. 155p.

Bonetti Filho I. 2000. Tratamento de canal radicular de dentes de cães com necrose pulpar e lesão periapical crônica induzida, realizado em sessão única e duas sessões utilizando três diferentes curativos de demora. Avali- ação Radiográfica, histopatológica e histomicrobiológica. Tese de LivreDocência, Faculdade de Odontologia, Universidade Estadual Paulista, Araraquara. 336p.

Brown J.H. \& Hopps H.C. 1973. Staining of bacteria in tissue sections: a reliable Gram stain method. Am. J. Clin. Pathol. 60(2):234-40.

Chong B.S. \& Pitt Ford T.R. 1992. The role of intracanal medication in root canal treatment. Int. Endodon. J. 25:290-297.

Gioso M.A. 2003. Odontologia Veterinária: pequenos animais. $2^{\underline{a}}$ ed. Fac. Med. Vet. Zootec., USP, São Paulo. 45p.

Harvey C.E. \& Emily P.P. 1993. Small Animal Dentistry. Mosby-Year Book, St Louis. 413p.

Holland R., Sant'Anna Junior A., Souza V., Dezan Junior E., Otoboni Filho J.A, Bernabé P.F.E., Nery M.J. \& Murata S.S. 2005. Influence of apical patency and filling material on healing process of dogs' teeth with vital pulp after root canal therapy. Braz. Dent. J. 16(1):9-16.

Leonardo M.R., Silva L.A., Leonardo R. De T., Utrilla L.S. \& Assed S. 1993. Histological evaluation of therapy using a calcium hydroxide dressing for teeth with incompletely formed apices and periapical lesions. J. Endodon. 19:348-352.

Silveira F.F. 1997. Efeito do tempo de ação do curativo de demora à base de hidróxido de cálcio, utilizado em canais radiculares de dentes de cães com lesão periapical crônica induzida. Análise histopatológia e microbiológica. Dissertação de Mestrado em Endodontia, Faculdade de Odontologia, Universidade Estadual Paulista, Araraquara. 218p.

Sipert C.R., Hussne R.P., Nishiyama C.K. \& Torres S.A. 2005. In vitro antimicrobial activity of fill canal, sealapex, mineral trioxide aggregate, Portland cement and endorez. Int. Endodon. J. 38:539-543.

Soares J.A. 1999. Estudo microbiológico dos canais radiculares, histopatológico e histobacteriológico dos tecidos apicais e periapicais, em função do preparo biomecânico e de dois curativos de demora à base de hidróxido de cálcio, utilizados em dois períodos de avaliação, no tratamento endodôntico de dentes de cães, com reação periapical crônica induzida. Dissertação de Mestrado em Endodontia, Faculdade de Odontologia, Universidade Estadual Paulista, Araraquara. 453p.

Wada M., Takase T., Nakanuma K., Arisue K., Nagahama F. \& Yomazaki M. 1998. Clinical study of refractory apical periodontitis treated by apicectomy part I. Root canal morphology of resected apex. Int. Endodon. J. 31:53-56. 